\title{
Relative Performance of Strawberry Cultivars from California and other North American Sources in Fumigated and Nonfumigated Soils
}

\author{
Douglas V. Shaw \\ Pomology Department, University of California, Davis, CA 95616 \\ Kirk D. Larson \\ South Coast Research and Extension Center, Irvine, CA 92718 \\ Additional index words. methyl bromide, chloropicrin, germplasm origin, Fragaria $\times$ ananassa
}

\begin{abstract}
Performance characteristics for eighteen strawberry cultivars (Fragaria $\times$ ananassa), nine from California and nine from other North American sources, were evaluated in annual hill culture, with and without preplant soil fumigation

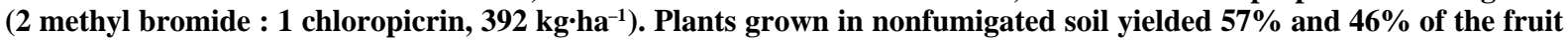
produced by plants on adjacent fumigated soil for cultivars from California and other North American origins, respectively. Plants in nonfumigated soils also developed fruit with lower berry weight $(94 \%$ and $95 \%$ of fumigated trials) and smaller spring plant diameter $(83 \%$ and $76 \%)$ for California and other sources, respectively. Trait values for exotic cultivars ranged from $39 \%$ to $80 \%$ of those for California cultivars, and the variance component due to germplasm sources explained $41 \%$ to $81 \%$ of the phenotypic variance of random effects in the experiment. Conversely, significant germplasm source $\times$ fumigation interactions were not detected for any of the growth or performance traits evaluated, and the proportion of variance attributable to these interactions was at most $2 \%$ of that due to germplasm source. These results demonstrate that strawberry growth and productivity for California and other North American germplasm sources are increased similarly by fumigation. Despite differing selection history, germplasm developed outside of California contains no obvious genetic diversity useful for developing cultivars specifically adapted to the sublethal effects of organisms in nonfumigated soils.
\end{abstract}

Research conducted during the past 50 years has demonstrated the benefits of soil fumigation for strawberry productivity in annual production systems (Himelrick and Dozier, 1991; Wilhelm et al., 1974; Wilhelm and Paulus, 1980). Recently, studies have demonstrated the importance of disinfested soil to all components of the annual production system, including the foundation and production nurseries that ultimately provide planting stock for the annually planted fruiting fields (Larson and Shaw, 1995a, 1995b). Despite these demonstrable benefits, economic factors and challenges to the availability of effective soil fumigants have mandated examination of alternative methods for sustaining these highly productive systems.

Recent efforts to improve strawberry performance in nonfumigated soils through genetics and breeding have emphasized the need for reducing plant mortality due to lethal pathogens and obtaining enhanced tolerance to the sublethal or competitive effects of soil organisms (Fort et al., 1996; Galletta et al., 1989; Larson and Shaw, 1995a; Yuen et al., 1991). Investigations of genetic alternatives to preplant soil fumigation within the Univ. of California (UC) breeding population have detected variation for resistance to several lethal pathogens (Shaw et al., 1996; Winterbottom, 1990). Although resistance to most lethal pathogens is partial and characterized by complex inheritance (Galletta et al., 1989, Shaw et al. 1996), improvement of breeding population and individual genotypic resistance levels are likely over multiple cycles of breeding, testing, and selection. Solutions to the consequences of sublethal organisms in nonfumigated soils have proven more elusive. To date, experiments with UC germplasm have not identified genetic variation useful in mitigating the

Received for publication 7 Dec. 1995. Accepted for publication 26 Mar. 1996. The cost of publishing this paper was defrayed in part by the payment of page charges. Under postal regulations, this paper therefore must be hereby marked advertisement solely to indicate this fact. consequences of sublethal soil organisms (Fort et al., 1996; Larson and Shaw, 1995a). Because these nonspecific causes can reduce productivity by $50 \%$ or more, sublethal soil organisms will remain an obstacle to strawberry management on nonfumigated soils even if cultivars with sufficient resistance to lethal pathogens are developed.

Although the cultivars developed in the UC program share a common ancestral base with cultivars developed elsewhere in North America (Sjulin and Dale, 1987), their recent selection histories can differ substantially. Importantly, the California strawberry industry and the UC cultivar development program have evaluated and selected genotypes in fumigated soils since the early 1970s, whereas many other North American production regions and their respective breeding programs use preplant soil fumigation rarely. Variation for adaptation to the effects of sublethal soil organisms has been rendered effectively neutral during the past 25 years of the UC program and may have been reduced in magnitude due to genetic sampling. Alternatively, differences in the genetic variation available in California and other North American sources might result if the genetic combinations that confer adaptation in nonfumigated soils are poorly adapted to performance in fumigated soils. The purpose of this study was to determine whether germplasm sources outside of the UC program may contain genetic variation useful in mitigating the effects of sublethal soil organisms.

\section{Materials and Methods}

Field trials were established at the UC Watsonville Strawberry Research Facility in the central coast of California. Adjacent plots were prepared for planting and either treated with 2 methyl bromide : 1 chloropicrin at $392 \mathrm{~kg} \cdot \mathrm{ha}^{-1}$, or left untreated. The Watsonville plantation was established on soil that had been cropped with strawberry in alternate years during the past 14 
Table 1. Expected mean squares for analysis of variance for four vegetative growth and performance traits.

\begin{tabular}{lcl}
\hline \hline Source & df & Expected mean squares \\
\hline Fumigation (F) & 1 & $\sigma^{2}+\mathrm{k}_{5} \sigma_{\mathrm{b} / \mathrm{f}}^{2}+\mathrm{k}_{6} \sigma_{\mathrm{f}}^{2}$ \\
Block/F & 2 & $\sigma^{2}+\mathrm{k}_{5} \sigma_{\mathrm{b} / \mathrm{f}}^{2}+\mathrm{k}_{2} \sigma_{\mathrm{c} / \mathrm{s}}^{2}+\mathrm{k}_{3} \sigma_{\mathrm{fxs}}^{2}+\mathrm{k}_{4} \sigma_{\mathrm{s}}^{2}$ \\
Germplasm source (S) & 1 & $\sigma^{2}+\mathrm{k}_{1} \sigma_{\mathrm{fxc} / \mathrm{s}}^{2}+\mathrm{k}_{3} \sigma_{\mathrm{fxs}}^{2}$ \\
$\mathrm{~F} \times \mathrm{S}$ & 1 & $\sigma^{2}+\mathrm{k}_{1} \sigma_{\mathrm{fxc} / \mathrm{s}}^{2}+\mathrm{k}_{2} \sigma_{\mathrm{c} / \mathrm{s}}^{2}$ \\
Cultivar (C/S) & 16 & $\sigma^{2}+\mathrm{k}_{1} \sigma_{\mathrm{fxc} / \mathrm{s}}^{2}$ \\
$\mathrm{~F} \times \mathrm{C} / \mathrm{S}$ & 16 & $\sigma^{2}+\mathrm{k}_{1} \sigma_{\mathrm{fxc} / \mathrm{s}}^{2}$ \\
Error & 34 & $\sigma^{2}$ \\
\hline
\end{tabular}

${ }^{\mathrm{z}}$ Coefficients $\mathrm{k}_{1}=2, \mathrm{k}_{2}=4, \mathrm{k}_{3}=18, \mathrm{k}_{4}=36, \mathrm{k}_{5}=18$, and $\mathrm{k}_{6}=36$

seasons - even production seasons alternated with a cover crop of barley (Hordeum vulgare L.) and Fava bean (Vicia faba L.). During the first 12 seasons, each strawberry production cycle was initiated with soil fumigation using 2 methyl bromide : 1 chloropicrin at $392 \mathrm{~kg} \cdot \mathrm{ha}^{-1}$. The soil used for nontreated plots in this experiment had been cropped twice with strawberries and twice with a cover crop since the last fumigation treatment.

Runner plants from nine California strawberry cultivars and nine widely used cultivars from other North American sources were harvested from a the UC Davis Pomology Dept.'s Wolfskill Experimental Orchard near Winters, Calif., on 4 Nov. 1994, stored at $2^{\circ} \mathrm{C}$, and planted in experimental plots on 14 Nov. (Rariden and Shaw, 1994). The nine California cultivars ('Camarosa', 'Carlsbad', 'Chandler', 'Cuesta', 'Irvine', 'Laguna', 'Seascape', 'Selva', and 'Sunset') were representative of those released from the UC strawberry improvement program during the last 15 years. Four of the California cultivars were day-neutral and the remainder were short-day types with a range of production patterns. Cultivars from other North American sources ('Earliglow', 'Guardian', 'Hood', 'Lateglow', 'Rainier', 'Raritan', 'Scott', 'Tribute', and 'Tristar') have been recommended for use in a number of locations including the northwestern, northeastern, lower midwestern, and mid-Atlantic regions of North America (Chandler, 1991). Two of the nonCalifornia cultivars, 'Tribute' and 'Tristar', were day-neutral types and the rest were short-day cultivars.

Trials were established and treated according to recommendations for commercial winter plantings (Welch, 1989), with modi- fications previously described for plantations established using low-elevation nursery sources (Rariden and Shaw, 1994; Voth and Bringhurst, 1990). Experimental plots were established on tworow diagonal beds with $1.5-\mathrm{m}$ centers, $33 \mathrm{~cm}$ between plants along rows, and $30 \mathrm{~cm}$ between rows. Each treatment was replicated twice, with a single plot of 20 plants per block. Fruit yield, a 10fruit weight, and a commercial appearance score were recorded weekly for 25 consecutive weeks with harvest initiated on 12 Mar. 1995. The commercial appearance score was assigned to the fruit harvested from each plot as an integer value of 1 to 5, with larger values indicating more desirable appearance (Rariden and Shaw, 1994). Total yield was evaluated for each plot on a per-plant basis. Seasonal fruit weights and appearance scores were calculated as the weighted average of the weekly 10-fruit weights or appearance scores over the season, with weighting based on weekly yield. Cross-sectional plant diameters were obtained on 7 Mar. to evaluate early vegetative growth (Shaw, 1993).

Large differences in the scale of response for yield were generated by the fumigation treatments, and an appropriate power transformation was performed before further analyses (Fernandez, 1992); significant scale effects were not detected for other variables and they were analyzed without transformation.

Data for all traits were subjected to ANOVA using SAS's GLM procedure (SAS Institute, Cary, N.C.). Fumigation treatment was considered a fixed effect and blocks nested in fumigation treatments as random effects; all interactions with blocks in treatments were pooled into a common error term. Germplasm source, culti-

Table 2. Means, standard deviations (in parentheses), and ranges (in brackets) for four growth and productivity traits for strawberry cultivars from California and other North American (ONA) sources grown with two preplant soil fumigation treatments at Watsonville, Calif.

\begin{tabular}{|c|c|c|c|c|c|}
\hline Fumigation $^{z}$ & $\begin{array}{l}\text { Germplasm } \\
\text { source }\end{array}$ & $\begin{array}{l}\text { March } \\
\text { plant } \\
\text { diam } \\
(\mathrm{cm})\end{array}$ & $\begin{array}{l}\text { Yield } \\
\text { per } \\
\text { plant } \\
(\mathrm{g})\end{array}$ & $\begin{array}{c}\text { Fruit } \\
\text { wt } \\
\text { (g/fruit) }\end{array}$ & $\begin{array}{l}\text { Weighted } \\
\text { fruit } \\
\text { appearance }\end{array}$ \\
\hline \multirow[t]{6}{*}{-} & California & 18.2 & 733 & 23.7 & 3.29 \\
\hline & & (3.2) & $(345)$ & (4.3) & $(0.33)$ \\
\hline & & [15.1-22.5] & [218-1357] & [18.2-33.1] & [3.00-3.91] \\
\hline & ONA & 13.9 & 263 & 16.9 & 2.43 \\
\hline & & (3.1) & (207) & (3.0) & $(0.33)$ \\
\hline & & [11.0-16.3] & [85-786] & [14.3-21.2] & [1.9-2.9] \\
\hline \multirow[t]{6}{*}{+} & California & 22.0 & 1296 & 25.3 & 3.20 \\
\hline & & (3.2) & (355) & (2.7) & $(0.24)$ \\
\hline & & [18.1-25.2] & [805-1641] & [21.9-30.3] & [3.0-3.81] \\
\hline & ONA & 18.4 & 577 & 17.8 & 2.41 \\
\hline & & (4.1) & (311) & (2.4) & $(0.20)$ \\
\hline & & [13.9-26.9] & [296-1308] & [14.1-21.9] & {$[2.1-2.7]$} \\
\hline
\end{tabular}

zThe symbols - and + indicate no soil fumigation and preplant soil fumigation with $392 \mathrm{~kg} \cdot \mathrm{ha}^{-1}$ of 2 methyl bromide : 1 chloropicrin (by weight), respectively; $\mathrm{N}=18$ all treatment means. 
vars nested in source, and their interactions with fumigation treatment were treated as random effects. Significance tests were performed using type III expected mean squares (Table 1). Model variance components due to source of origin $\left(\sigma_{\mathrm{s}}^{2}\right)$, cultivars in source $\left(\sigma_{\mathrm{c} / \mathrm{s}}^{2}\right)$, source $\times$ fumigation treatment interaction $\left(\sigma_{\mathrm{fs}}^{2}\right)$, cultivar in source $\times$ fumigation treatment interaction $\left(\sigma_{\mathrm{fc} / \mathrm{s}}^{2}\right)$, and error $\left(\sigma^{2}\right)$ were estimated by equating the expected mean squares in Table 1 with their corresponding experimental mean squares and solving this series of linear equations. Variance components were expressed as the proportion of the total phenotypic variance of random effects in the experiment $\left(\sigma_{\mathrm{p}}^{2}\right)$, where

$\sigma_{\mathrm{p}}^{2}=\sigma_{\mathrm{s}}^{2}+\sigma_{\mathrm{c} / \mathrm{s}}^{2}+\sigma_{\mathrm{fs}}^{2}+\sigma_{\mathrm{fc} / \mathrm{s}}^{2}+\sigma^{2}$

\section{Results and Discussion}

Mortality was $<1 \%$ for plants established in fumigated and nonfumigated soils, and no visual symptoms of lethal pathogens were observed. As for previous trials conducted at this location, the main effects of fumigation treatment in these experiments must be due to sublethal effects of soil organisms (Larson and Shaw, 1995a; Yuen et al., 1991).

Fumigation resulted in increased plant growth, productivity, and fruit weight for cultivars from both sources (Table 2, Fig. 1). Fumigation response for vegetative plant vigor was observed as differences in March cross-sectional plant diameters; plants grown in nonfumigated soils had diameters $83 \%$ and $76 \%$ of those for plants in fumigated soils for cultivars of California and other North American origin, respectively. Consistent with previous experiments (Larson and Shaw, 1995a), productivity was the trait most affected by preplant soil treatment: plants grown on nonfumigated soil yielded $57 \%$ and $46 \%$ of the fruit produced by plants evaluated on adjacent fumigated soil for cultivars from California and other North American sources. Plants grown in nonfumigated soils also produced somewhat smaller fruit than those in fumigated soils (94\% and 95\% for California and other sources), but soil treatment had no detectable effect on fruit appearance.

Large differences in trait means were also found due to germplasm source of origin (Table 2). Cultivars from other North American sources had somewhat smaller plants than California cultivars (March diameter $80 \%$ of California cultivars) and produced $39 \%$ of the total yield of California cultivars. Differences among sources were also apparent for average fruit weight and fruit appearance scores (Table 2). These results are consistent with those obtained previously for tests conducted in fumigated soils alone (Rariden and Shaw, 1994).

The large apparent fumigation treatment effects and germplasm source differences were further evaluated using ANOVA. Fumigation treatment effects were significant $(P<0.05)$ for all traits except fruit appearance score (Table 3 ). Direct comparisons of the magnitude of soil treatment effects with those due to the genetics of germplasm source are not valid. However, the observation that California cultivars had greater yield and larger fruit in nonfumigated soils than other North American cultivars in fumigated soils suggests that the obstacles to directional infusion of germplasm will be substantial.

The variance component due to source of origin was highly significant $(P<0.01)$ for all traits evaluated (Table 3$)$ and explained the largest fraction of the variance of random effects in the experiment $\left(\sigma^{2}=63 \%\right.$ to $\left.81 \%\right)$ for all traits except plant diameter $\left(\sigma_{\mathrm{s}}^{2}=41 \%\right)$. Conversely, significant germplasm source $\times$ fumigation interactions were not detected for any of the growth or performance traits. The proportion of variance attributable to source $\times$ fumigation interactions $\left(\sigma_{\mathrm{fs}}^{2}\right)$ was at most $2 \%$ of that due to the main effects of germplasm source. These results demonstrate that strawberry growth, productivity, and fruit quality for California and other North American germplasm sources are increased similarly by fumigation.

Substantial and highly significant variances were detected among cultivars within germplasm source for all traits (Table 3), indicating that genotypic variation is present even within these rather highly selected sets of cultivars. Genotypic means cover a substantial range within each source (Table 2), and some overlap of source ranges exists for all traits and fumigation treatments except fruit appearance. However, the range shared between sources is a fraction of the total (Fig. 1) and, except for plant diameter, the within-source variance for all traits was small $\left(\sigma^{2}{ }_{c / s}\right.$ $=9 \%$ to $30 \%$ of $\sigma_{\mathrm{p}}^{2}$ ) compared with that due to differences among sources $\left(\sigma_{\mathrm{s}}^{2}=41 \%\right.$ to $\left.81 \%\right)$. Likewise, cultivar in source $\times$ fumigation treatment interaction variances $\left(\sigma_{\text {fc/s }}^{2}\right)$ were significant in three of four cases but explained only $2 \%$ to $5 \%$ of the phenotypic variance of random effects; thus, the main effects of sublethal soil organisms in this experiment affected all cultivars similarly.

The cultivars tested here comprise a small but representative sample of the genotypes currently available and recommended for use in annual and perennial productions systems. Because the cultivars in each set are the result of intensive testing and selection programs, the estimates of genetic variance obtained here must be
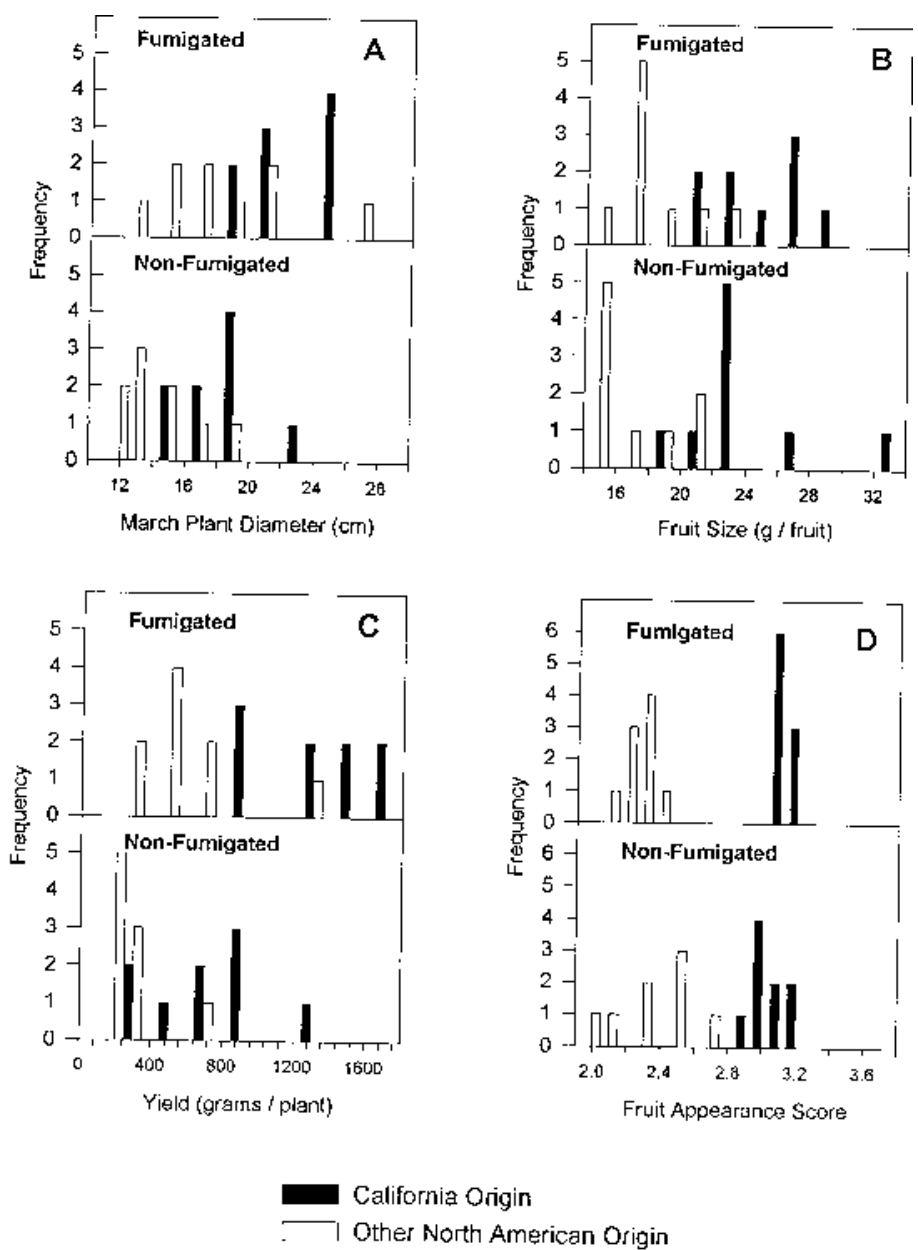

Fig. 1. Distribution patterns of genotypic mean values by fumigation treatment for (a) seasonal yield, (b) fruit size, (c) fruit appearance score, and (d) March plant diameter. 
Table 3. Results of analysis of variance for four growth and productivity traits for strawberry cultivars from California and other North American sources grown with two preplant soil fumigation treatments at Watsonville, Calif.

\begin{tabular}{|c|c|c|c|c|}
\hline \multirow[b]{2}{*}{ Source } & \multicolumn{4}{|c|}{ Mean squares } \\
\hline & $\begin{array}{l}\text { March } \\
\text { plant } \\
\text { diam } \\
(\mathrm{cm})\end{array}$ & $\begin{array}{l}\text { Yield } \\
\text { per } \\
\text { plant } \\
(\mathrm{g})\end{array}$ & $\begin{array}{c}\text { Fruit } \\
\text { wt } \\
(\mathrm{g})\end{array}$ & $\begin{array}{l}\text { Weighted } \\
\text { fruit } \\
\text { appearance }\end{array}$ \\
\hline Fumigation (F) & $307.9^{*}$ & $14,909^{*}$ & $28.9^{*}$ & 0.061 \\
\hline Replication (R/F) & $94.5^{* *}$ & $295^{* *}$ & 3.1 & $0.111^{* *}$ \\
\hline Source $(\mathrm{S})$ & $275.7^{* * *}$ & $26,894^{* *}$ & $907.4^{* *}$ & $12.417^{\text {** }}$ \\
\hline $\mathrm{F} \times \mathrm{S}$ & 2.0 & 302 & 2.2 & 0.040 \\
\hline Cultivar (C)/S & $32.1^{* *}$ & $1,435^{* *}$ & $32.2^{* *}$ & $0.221^{* *}$ \\
\hline $\mathrm{F} \times \mathrm{C} / \mathrm{S}$ & 2.5 & $86^{* *}$ & $6.2^{* *}$ & $0.064^{* *}$ \\
\hline Error & 1.9 & 29 & 1.8 & 0.021 \\
\hline$\sigma^{2 z}$ & $6.78(41)$ & $701.2(63)$ & $24.43(70)$ & $0.339(81)$ \\
\hline$\sigma_{\mathrm{fxs}}^{2}$ & $0(0)$ & $12.0(1)$ & $0(0)$ & $0(0)$ \\
\hline$\sigma^{{ }^{\mathrm{fxs}}}$ & $7.40(45)$ & $337.3(30)$ & $6.50(19)$ & $0.039(9)$ \\
\hline$\sigma_{f x c s}^{c / s}$ & $0.34(2)$ & $28.5(3)$ & $2.21(6)$ & $0.022(5)$ \\
\hline$\sigma_{p}^{2^{f x c / s}}$ & 16.42 & $1,108.0$ & 34.94 & 0.421 \\
\hline
\end{tabular}

${ }^{\mathrm{z}}$ Variance component values labeled 0 were small and negative; values in parentheses are percent of the total phenotypic variance of random effects, $\sigma^{2}$.

**** Significant at $P=0.05$ or 0.01 , respectively.

interpreted with some caution. Differences among cultivars within each source of origin provide minimum estimates of the variation available within respective breeding populations, and questions regarding population-specific genetic and genetic $\times$ fumigation interaction variance may be better addressed with segregating genetic samples (Fort et al., 1996; Larson and Shaw, 1995a). Conversely, a sample of nine genotypes from each source should be adequate to elucidate any consistent pattern of interaction between source of origin and the two fumigation treatments tested here.

The genetic differences observed among the cultivars tested here were expressed consistently across fumigated and nonfumigated soils, regardless of their origin or intended production system. Despite differing selection history, germplasm developed outside of California offers no obvious genetic diversity useful for developing cultivars specifically adapted to the sublethal effects of organisms in nonfumigated soils.

\section{Literature Cited}

Chandler, C.K. 1991. North American strawberry cultivars. Chapter 8. In: A. Dale and J.J. Luby (eds.). The strawberry into the 21 st century. Timber Press, Portland, Ore.

Fernandez, G.C.J. 1992. Residual analysis and data transformations: Important tools in statistical analysis. HortScience 27:297-300.

Fort, S.B., D.V. Shaw, and K.D. Larson. 1996. Performance responses of strawberry seedlings to the sublethal effects of nonfumigated soils. J. Amer. Soc. Hort. Sci. 121:367-370.

Galletta, G.J., A.D. Draper, and J.L. Maas. 1989. Combining disease resistance, plant adaptation, and fruit quality in breeding short-day and day-neutral strawberries. Acta Hort. 265:43-51.

Himelrick, D.G. and W.A. Dozier. 1991 Soil fumigation and soil solariza- tion in strawberry production. Adv. Straw. Prod. 10:12-28.

Larson, K.D. and D.V. Shaw. 1995a. Relative performance of strawberry genotypes in fumigated and nonfumigated soil. J. Amer. Soc. Hort. Sci. 120:274-277.

Larson, K.D. and D.V. Shaw. 1995b. Strawberry nursery soil fumigation and runner plant production. HortScience 30:236-237.

Rariden, J.M. and D.V. Shaw. 1994. Performance of North American strawberry cultivars under conditions mimicking California production systems. J. Amer. Soc. Hort. Sci. 119:1034-1038.

Shaw, D.V. 1993. Genetic correlations between vegetative growth traits and productivity at different within-season intervals for strawberries. Theor. Appl. Genet. 85:1001-1009.

Shaw, D.V., W.D. Gubler, K.D. Larson, and J. Hansen. 1996. Genetic variation for field resistance to Verticillium dahliae evaluated using genotypes and segregating progenies of California strawberries. J. Amer. Soc. Hort. Sci. 121:625-628.

Sjulin T.M. and A. Dale. 1987. Genetic diversity of North American strawberry cultivars. J. Amer. Soc. Hort. Sci. 112:375-385.

Voth, V. and R.S. Bringhurst. 1990. Cultural and physiological manipulation of strawberries. HortScience 25:889-892.

Welch, N. 1989. Strawberry production in California. Univ. of California Coop. Ext. Lflt. 2959.

Wilhelm, S. and A.O. Paulus. 1980. How soil fumigation benefits the California strawberry industry. Plant. Dis. 64:264-270.

Wilhelm, S., R.C. Storkan, and J.M. Wilhelm. 1974. Preplant soil fumigation with methyl bromide-Chloropicrin mixtures for control of soilborne diseases of strawberries-A summary of fifteen years of development. Agr. Environ. 1:227-236

Winterbottom, C.Q. 1990. Resistance of strawberry to Colletotrichum acutatum. Hort. MS thesis. Univ. of Calif., Davis.

Yuen, G.Y., M.N. Schroth, A.R. Weinhold, and J.G. Hancock. 1991. Effects of soil fumigation with methyl bromide and chloropicrin on root health and yield in strawberry. Plant Dis. 75:416-420. 